\title{
Memória do câncer
}

O Projeto Memória da Luta Contra o Câncer no Brasil, que se vem desenvolvendo no Departamento de Ciências Sociais da ENSP/FIOCRUZ a partir de setembro de 1984, situa-se numa proposta mais ampla de consolidação de uma linha de pesquisa voltada para a reconstrução histórica das políticas de saúde no paŕs. Fruto de convênio entre a Campanha Nacional de Combate ao Câncer/ENSP/FIOCRUZ, adotou como tema central, na primeira fase da investigação, o desenvolvimento histórico da política institucional de combate ao câncer, em especial a história do Instituto Nacional do Câncer, que resultou no relatório "contribuição à História da Luta Contra o Câncer no Brasil”, elaborado em fevereiro de 1985.

Procurando aprofundar as questões suscitadas no primeiro relatório, o convênio estendeu-se para 85 . Neste sentido, iniciou-se uma nova fase da pesquisa tendo como objetivo perceber em que medida as práticas voltadas para o câncer encontram significação dentro do quadro mais geral das políticas de saúde, observando suas relações com as conjunturas político-econômicas do Brasil.

A pesquisa encontra-se em fase de redação do relatório final que, posteriormente, será publicado pelo Programa de Educação Continuada (PEC) da Escola Nacional de Saúde Pública, na série "Memórias da Saúde Pública".

Regina C. Bodstein 